\title{
Parasitoids of Chrysopidae Eggs in Sinaloa Mexico
}

\author{
María de Lourdes Ramírez-Ahuja ${ }^{1}$, Enrique Garza-González ${ }^{2}$, Elijah J. Talamas ${ }^{3}$, \\ Mayra A. Gómez-Govea ${ }^{1}$, Mario A. Rodríguez-Pérez ${ }^{4}$, Patricia Zambrano-Robledo ${ }^{5}$, \\ Eduardo Rebollar-Tellez ${ }^{1}$ and Iram P. Rodríguez-Sanchez ${ }^{1, *(\mathbb{D}}$
}

1 Laboratorio de Fisiología Molecular y Estructural, Facultad de Ciencias Biológicas, Universidad Autónoma de Nuevo León, San Nicolás de Los Garza 66450, Mexico; lulu.ahuja@hotmail.com (M.d.L.R.-A.); mayragee@gmail.com (M.A.G.-G.); eddie_the_little@yahoo.com (E.R.-T.)

2 Agrobionsa, Agrobiológicos del Noreste, Calle Rio Mocorito 575 pte, Guadalupe, Culiacán Rosales 80220, Mexico; egarzag9@hotmail.com

3 Florida State Collection of Arthropods, Division of Plant Industry, Florida Department of Agriculture and Consumer Services, Gainesville, FL 32608, USA; elijah.talamas@fdacs.gov

4 Centro de Biotecnología Genómica, Instituto Politécnico Nacional, Reynosa 88710, Mexico; marodriguez7862@hotmail.com

5 FIME-Centro de Investigación e Innovación en ingeniería Aeronáutica (CIIIA), Universidad Autónoma de Nuevo León, Av. Universidad s/n, Ciudad Universitaria, San Nicolás de los Garza 66455, Mexico; patricia.zambranor@uanl.edu.mx

* Correspondence: iramrodriguez@gmail.com; Tel.: +52-(81)-83294110 (ext. 3676)

Received: 12 September 2020; Accepted: 16 November 2020; Published: 30 November 2020

Simple Summary: Four species of wasps, Myartsevaia chrysopae, Telenomus lobatus, Telenomus tridentatus and Trichogramma atopovirilia, are recorded as parasitoids of chrysopid eggs in Mexico, for the first time. The field survey was conducted in sorghum and corn in different locations in Sinaloa, Mexico. The identification of the parasitoids was determined by morphology, and for both Telenomus species the barcode region of the cytochrome oxidase 1 gene (CO1) was amplified and sequenced.

Abstract: The eggs parasitoids Myartsevaia chrysopae (Crawford) (Hymenoptera: Encyrtidae), Telenomus lobatus Johnson, Telenomus tridentatus Johnson (Hymenoptera: Scelionidae) and Trichogramma atopovirilia Oatman and Platner (Hymenoptera: Trichogrammatidae) are reported for the first time or in new localities in Mexico. Their occurrence was first discovered in 2018 during a survey of parasitism on chrysopid eggs, conducted on Sorghum bicolor L. Moench (Poales: Poaceae) and Zea mays L. (Poales: Poaceae) in different locations in Sinaloa, Mexico. The identity of the parasitoids was determined by morphology and for both species of Telenomus the barcode region of the cytochrome oxidase 1 gene (CO1) was generated to facilitate molecular diagnosis of these species in future studies.

Keywords: eggs parasitoids; Telenomus; crisopids; DNA barcoding

\section{Introduction}

Members of the insect family Chrysopidae (Neuroptera), commonly known as green lacewings, are important biological control agents as predators of several insect pests of agriculture. They have been reported preying on Diaphorina citri Kuwayama (Hemiptera: Liviidae) [1], whiteflies (Hemiptera: Aleyrodidae), Parlatoria (Genaparlatoria) pseudaspidiotus Lindinger (Hemiptera: Diaspididae) [2,3], and Melanaphis sacchari (Zehntner) (Hemiptera: Aphididae). In areas where M. sacchari occurs in Mexico, Chrysoperla carnea (Stephens) (Neuroptera: Chrysopidae) are released to control the pest [4]. Although Ch. carnea is the only species that is released against $M$. sacchari, at least eight species of Chrysopidae have been reported preying on M. sacchari under field conditions in Sinaloa, Mexico [5]. 
Many species of parasitoid wasps in the families Scelionidae, Encyrtidae and Trichogrammatidae are important natural enemies of agricultural pests, and some species are known to parasitize chrysopid eggs [6]. Only one species in the family Encyrtidae, Myartsevaia chrysopae (Crawford, 1913) (= Ooencyrtus mexicanus Myartseva and Shuvakhina), has been reported as an egg parasitoid of Chrysopidae in Mexico (Tamaulipas) [6,7]. Within Scelionidae, at least six species of Telenomus have been reported as eggs parasitoids of Neuroptera: Te. chrysopae Ashmead, Te. ampullaceus Johnson and Bin, Te. suvae Johnson and Bin, Te. lobatus Johnson and Bin, Te. tridentatus Johnson and Bin [8], and Te. chrysoperlae Loiácono [9]. Within Trichogrammatidae Trichogramma tajimaense Yashiro, Hirose and Honda and Tr. semblidis (Aurivillius) have been recorded as egg parasitoids of Neuroptera [10]. There have been few studies on the life histories of these parasitoids and their potential impact on the effectiveness of chrysopid as biological control agents [11,12] despite reports of more than 50\% parasitism of Chrysoperla eggs by Te. lobatus [11]. To date, there is also almost no information about egg parasitoids of Chrysopidae in Mexico. Therefore, this study was conducted to identify parasitoids of chrysopid eggs, provide additional information about their biology, and determine their parasitism rates in sorghum and corn crops in Culiacan, Mexico.

\section{Materials and Methods}

\subsection{Biological Samples}

Parasitoids were obtained from field-collected chrysopid eggs on the leaves of Sorghum bicolor (L.) Moench (Poales: Poaceae) and Zea mays L. (Poales: Poaceae) in different locations in Sinaloa, Mexico during June and August 2018 (Table 1) and May and June 2019 (Table 2). Fifty leaves with eggs of Chrysopidae on their surfaces were cut and taken to the laboratory ( $\left.\mathrm{RH} 70 \%, 25 \pm 2{ }^{\circ} \mathrm{C}\right)$. Each egg was individually placed into a $3 \mathrm{~cm}$ plastic box. Eggs of Sitotroga cerealella (Olivier) (Lepidoptera: Gelechiidae) were also placed in the box to feed the chrysopid larvae when they emerged. Eggs were kept under observation until the emergence of lacewings or adult parasitoids. Parasitoids that emerged were placed in $100 \%$ ethanol for morphological and molecular analyses. The number of eggs, emerged larvae, and parasitism rate were recorded.

\subsection{Morphological Identification}

We used the key of Johnson and Bin [8] to identify species of Telenomus, the keys of Pinto [13] for Trichogramma, and the keys of Myartseva and Shuvakhina [7] for Encyrtidae identification. For all of these groups, examination of the male genitalia is necessary for species-level determination. To prepare the slides of the male genitalia we followed the protocol of Polaszek and Kimani [14], which basically consists of permanent preparations in Canada balsam. The location of the emergence hole in the host egg and the color of the host egg are diagnostic for each of the species in this study. Once the males were associated with characteristics of the host egg, these were used to confirm the identity of the corresponding females. Larvae of Chysopidae were identified to species according to the keys of Tauber [15]. To identify chrysopid adults we used the key of Brooks [16] for Chrysoperla species and the key of Tauber [17] for Ceraeochrysa. All insect specimens were deposited in the Colección de Insectos Benéficos Entomófagos, Facultad de Ciencias Biológicas-Universidad Autónoma de Nuevo León. 
Table 1. Collection dates, localities, and number of chrysopid eggs collected in field surveys in Sinaloa during 2018.

\begin{tabular}{|c|c|c|c|c|c|c|c|}
\hline Locality & Coordinates & Date & Total Eggs & Parasitized Eggs & Parasitized by Tr. atopovirilia & Parasitized by Telenomus & Total Parasitism \\
\hline Guasave & $\begin{array}{r}25.56745 \mathrm{~N} \\
108.46756 \mathrm{~W} \\
\end{array}$ & 02-VI-2018 & 65 & 5 & 0 & $5=7.6 \%$ & $7.6 \%$ \\
\hline Guasave & $\begin{array}{c}25.56745 \mathrm{~N} \\
108.46756 \mathrm{~W}\end{array}$ & 06-VI-2018 & 44 & 5 & 0 & $5=11.3$ & $11.3 \%$ \\
\hline Guasave & $\begin{array}{c}25.56745 \mathrm{~N} \\
108.46756 \mathrm{~W}\end{array}$ & $10-\mathrm{VI}-2018$ & 65 & 19 & $8=12.3 \%$ & $11=16.92 \%$ & $29.23 \%$ \\
\hline Guasave & $\begin{array}{c}25.56745 \mathrm{~N} \\
108.46756 \mathrm{~W}\end{array}$ & 18-VI-2018 & 54 & 13 & $3=5.5 \%$ & $10=18.5 \%$ & $24 \%$ \\
\hline Guasave & $\begin{array}{c}25.56745 \mathrm{~N} \\
108.46756 \mathrm{~W}\end{array}$ & $20-\mathrm{VI}-2018$ & 42 & 7 & 0 & $7=16.7 \%$ & $16.7 \%$ \\
\hline Guasave & $\begin{array}{r}25.56745 \mathrm{~N} \\
108.46756 \mathrm{~W}\end{array}$ & 25-VI-2018 & 104 & 37 & $19=18.3 \%$ & $18=17.3 \%$ & $35.57 \%$ \\
\hline Guasave & $\begin{array}{c}25.56745 \mathrm{~N} \\
108.46756 \mathrm{~W}\end{array}$ & 01-VI-2018 & 115 & 17 & $2=1.7 \%$ & $15=13.4 \%$ & $14.78 \%$ \\
\hline El Dorado & $\begin{array}{c}24.3012560 \mathrm{~N} \\
107.3772660 \mathrm{~W}\end{array}$ & 19-VIII-2018 & 195 & 5 & 0 & $5=2.56 \%$ & $2.56 \%$ \\
\hline Tabalá & $\begin{array}{c}24.411330 \mathrm{~N} \\
107.092851 \mathrm{~W}\end{array}$ & 23-VIII-2018 & 60 & 3 & 0 & $3=5 \%$ & $5 \%$ \\
\hline El Dorado & $\begin{array}{c}24.354280 \mathrm{~N} \\
107.339325 \mathrm{~W}\end{array}$ & 25-VIII-2018 & 95 & 13 & $6=6.31 \%$ & $7=7.36 \%$ & $13.68 \%$ \\
\hline Culiacancito & $\begin{array}{l}24.848012 \mathrm{~N} \\
107.54137 \mathrm{~W}\end{array}$ & 28-VIII-2018 & 27 & 3 & 0 & $3=11.11 \%$ & $11.11 \%$ \\
\hline Total & & & 866 & 127 & \multicolumn{3}{|c|}{ Overall parasitism rate: $14.66 \%$} \\
\hline
\end{tabular}


Table 2. Collection dates, localities, and number of chrysopid eggs collected in field surveys in Sinaloa during 2019.

\begin{tabular}{|c|c|c|c|c|c|c|c|}
\hline Locality & Coordinates & Date & Total Eggs & Parasitized Eggs & Parasitized by Tr. atopovirilia & Parasitized by Telenomus & Total Parasitism \\
\hline Culiacancito & $\begin{array}{l}24.848012 \mathrm{~N} \\
107.54137 \mathrm{~W}\end{array}$ & $25-\mathrm{V}-2019$ & 293 & 94 & $8=2.73 \%$ & $75=25.59 \%$ & $11=3.75 \%$ \\
\hline Ingenio El Dorado & $\begin{array}{c}24.301390 \mathrm{~N} \\
107.377502 \mathrm{~W}\end{array}$ & 27-V-2019 & 143 & 38 & $9=6.29 \%$ & $17=11.88 \%$ & $12=8.39 \%$ \\
\hline Culiacancito & $\begin{array}{c}24.342222 \mathrm{~N} \\
107.368057 \mathrm{~W}\end{array}$ & $27-V-2019$ & 192 & 16 & $0 \%$ & $16=8.33$ & 0 \\
\hline IMPA Campo exp & $\begin{array}{c}24.572779 \mathrm{~N} \\
107.454445 \mathrm{~W}\end{array}$ & $29-V-2019$ & 75 & 13 & $0 \%$ & $13=17.33 \%$ & 0 \\
\hline Carretera IMPA & $\begin{array}{c}24.367777 \mathrm{~N} \\
107.370003 \mathrm{~W}\end{array}$ & $29-V-2019$ & 269 & 50 & $26=9.66 \%$ & $22=8.17 \%$ & $2=0.74 \%$ \\
\hline Ingenio El Dorado & $\begin{array}{c}24.342501 \mathrm{~N} \\
107.368332 \mathrm{~W}\end{array}$ & $29-V-2019$ & 71 & 11 & $2=2.81 \%$ & $6=8.45 \%$ & $3=4.22 \%$ \\
\hline Bebelamas & $\begin{array}{c}24.637222 \mathrm{~N} \\
107.273613 \mathrm{~W}\end{array}$ & $30-\mathrm{V}-2019$ & 51 & 3 & 0 & $3=5.88 \%$ & 0 \\
\hline Culiacán & $\begin{array}{c}24.633055 \mathrm{~N} \\
107.276665 \mathrm{~W}\end{array}$ & $30-\mathrm{V}-2019$ & 274 & 41 & $6=2.18 \%$ & $35=12.77 \%$ & 0 \\
\hline Paralelo 38 & $\begin{array}{c}24.599167 \mathrm{~N} \\
107.481941 \mathrm{~W}\end{array}$ & $30-V-2019$ & 77 & 15 & $5=6.49 \%$ & $9=11.68$ & $1=1.29 \%$ \\
\hline Total & & & 1445 & 281 & \multicolumn{3}{|c|}{ Overall parasitism rate: $19.44 \%$} \\
\hline
\end{tabular}




\subsection{Molecular Data}

Genomic DNA was nondestructively isolated from the whole specimen using the Qiagen DNeasy kit (Hilden, Germany) as described by Giantsis [18]. Polymerase chain reaction (PCR) was carried out to amplify the mt CO1 (Cytochrome Oxidase Subunit 1) barcode region using the LCO1490 and HCO2198 primers [19]. The PCR was performed in a $20 \mu \mathrm{L}$ reaction volume: $2 \mu \mathrm{L}$ of DNA, $2 \mu \mathrm{L}$ of $10 \times$ Qiagen PCR buffer containing $15 \mathrm{mM} \mathrm{MgCl}, 0.9 \mu \mathrm{L}$ of each primer, $0.6 \mu \mathrm{L}$ of dNTPs ( $25 \mathrm{mM}$ each), and $0.2 \mu \mathrm{L}$ of (5 U/ $\mu \mathrm{L})$ Taq DNA Polymerase (Qiagen, Hilden, Germany), and $13.4 \mu \mathrm{L}$ of $\mathrm{H}_{2} \mathrm{O}$. The PCR conditions were as follows: $94^{\circ} \mathrm{C}$ for $3 \mathrm{~min}$, followed by 40 cycles of $94{ }^{\circ} \mathrm{C}$ for $30 \mathrm{~s}, 52^{\circ} \mathrm{C}$ for $1 \mathrm{~min}, 72{ }^{\circ} \mathrm{C}$ for $1 \mathrm{~min}$ with a final extension at $72{ }^{\circ} \mathrm{C}$ for $10 \mathrm{~min}$. All PCR products were electrophoresed through agarose gel $(1 \%)$ and Sanger sequenced in both directions at the Florida Department of Agriculture Division of Plant Industry. Sequences were assembled and edited using Bioedit version 7. Vouche rspecimens were deposited at "Colección de Insectos Benéficos Entomófagos" (FCB-UANL) and the Florida State Collection of Arthropods (Gainesville-Florida). CO1 barcode sequences generated during this study were deposited in GenBank (Table 3).

Table 3. Accession number of CO1 sequences of Telenomus species.

\begin{tabular}{ccc}
\hline Species & Collection Unit Identifier & GenBank Accession Number \\
\hline Telenomus lobatus & FSCA 00091168 & MT846080 \\
Telenomus lobatus & FSCA 00091169 & MT846081 \\
Telenomus tridentatus & FSCA 00091170 & MT846082 \\
\hline
\end{tabular}

\section{Results}

A total of 2311 chrysopid eggs were collected across all sites surveyed in Sinaloa during 2018-2019 (Tables 1 and 2). Four species of parasitoids were recovered from 408 parasitized eggs: Myartsevaia chrysopae, Telenomus lobatus, Telenomus tridentatus and Trichogramma atopovirilia.

\subsection{Morphological Identification}

\subsubsection{Myartsevaia chrysopae (Crawford 1913)}

Comments: Myartsevaia chrysopae can be recognized by the short digiti illustrated in Figure 1B. The host egg, viewed externally, appears as is seen in Figure 1A after the emergence of $M$. chrysopae (Female Figure 1C), which exits through the sides of the eggs but never through the apex as does Te. lobatus (Figure 2B).
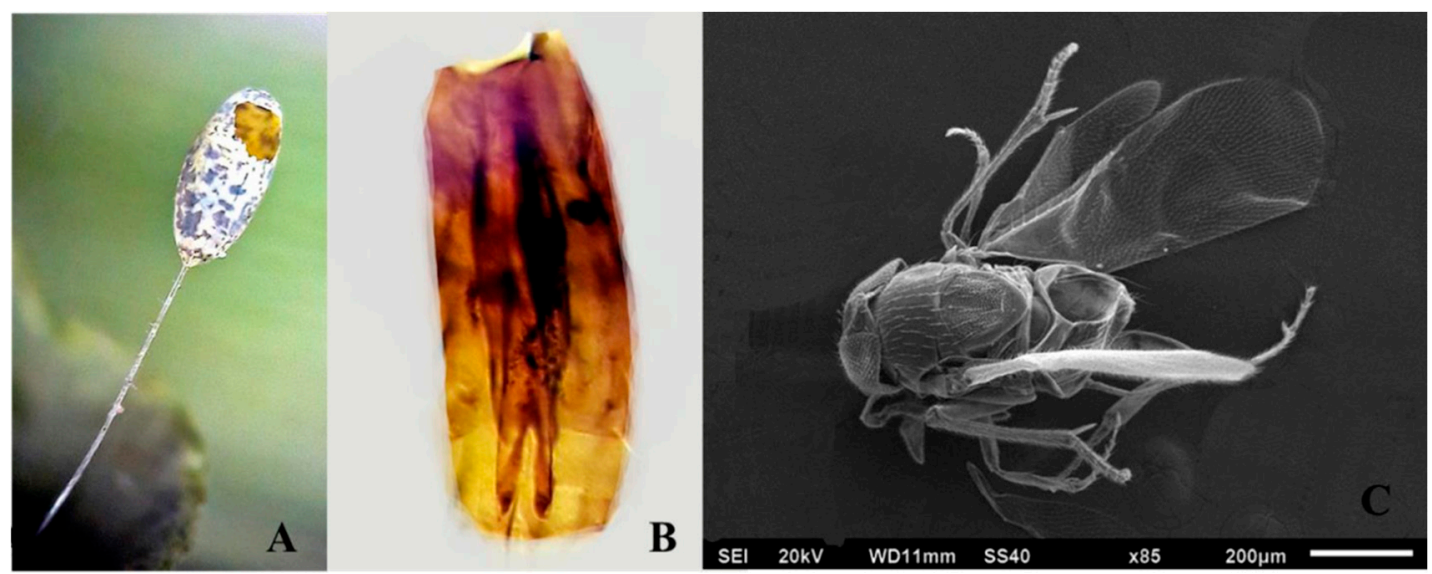

Figure 1. (A) Chorion of chrysopid egg following emergence of M. chrysopae, (B) Male genitalia, (C) Female M. chrysopae. 
Material examined: Mexico, Sinaloa, Culiacancito. 25-V-2019. Enrique Garza. $24848012-10754137$.

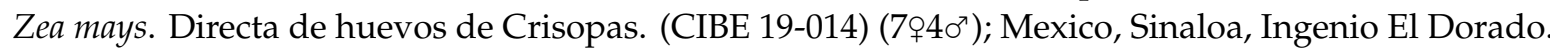
27-V-2019. M. L. Ramírez-Ahuja y Enrique Garza. 24.301390-107.377502. Zea mays. Directa de huevos de Chrysopidae (CIBE 19-015) (84ㅜㄱ); Mexico, Sinaloa, Culiacán, Carretera Campo experimental Impa El Dorado. 29-V-2019. M. L. Ramírez-Ahuja y Enrique Garza. 24.367777-107.370003. Zea mays. Directa de huevos de Chrysopidae (CIBE 19-018) (2o); México, Culiacán, Ingenio El Dorado. 29-V-2019. M. L. Ramírez-Ahuja y Enrique Garza. 24.342501-107.368332. Zea mays. Directa de huevos de Chrysopidae (CIBE 19-019) (2o10 ); Mexico, Sinaloa, Paralelo. 38. 30-V-2019. M. L. Ramírez-Ahuja y Enrique Garza. 24.599167-107.481941. Sorgo para grano. Directa de huevos de Crisopas (CIBE 19-022) (1ㅇ).

\subsubsection{Telenomus lobatus Johnson and Bin 1982}

Comments: Te. lobatus can be recognized by the digiti of the male genitalia with two long, widely separated teeth; lamina volsellaris in the form of a pair of strong, apically diverging rods or struts; aedeagal lobe which is extremely long and narrow (Figure $2 \mathrm{C}$ ). The host egg viewed externally appears pink when parasitized (Figure 2A) and after the emergence of Te. lobatus (Female Figure 2D) it appears as in Figure 2B. Telenomus lobatus emerges from the apex of the egg (Figure 2B).
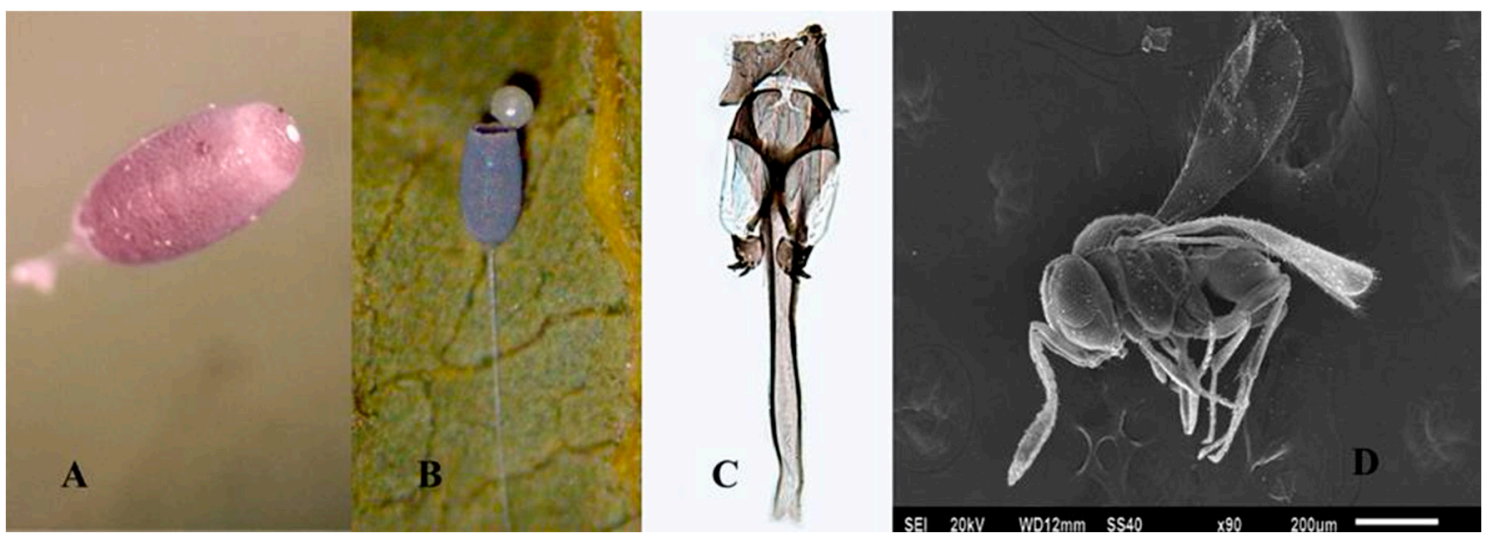

Figure 2. (A) Egg parasitized by Telenomus lobatus, (B) Chorion of Chrysopidae abandoned by Te. lobatus, (C) Male genitalia, (D) Female Te. lobatus.

Material examined: Mexico, Sinaloa, El Dorado, Ingenio El Dorado. 19-VIII-2018. Enrique Garza González. 24.3012560 107 3772660. Sorgo forrajero. En huevos de Chrysopidae (CIBE 18-020) (3웅ㄱ); Mexico, Carretera Culiacán-El Dorado. 25-VIII-2018. Enrique Garza González y María de Lourdes Ramírez Ahuja. 24.505119 107.439178. Sorgo forrajero. En huevos de Chrysopidae (CIBE 18-023) (6910`); Mexico, Culiacancito. 28-VIII-2018. Enrique Garza González y María de Lourdes Ramírez Ahuja. En maíz. Huevos de Chrysopidae (CIBE 18-027) (1\$207); México, Culiacancito. 25-V-2019. Enrique Garza. 248480 12-10754137. Zea mays. Directa de huevos de Crisopas. (CIBE 19-014) (15ф7॰ ); México, Sinaloa, Ingenio El Dorado. 27-V-2019. M. L. Ramírez-Ahuja y Enrique Garza. 24.301390-107.377502. Zea mays. Directa de huevos de Crisopas (CIBE 19-015) (4웅); Mexico, Culiacancito. 27-V-2019. M. L. Ramírez-Ahuja y Enrique Garza. 24.342222-107.368057. Zea mays. Directa de huevos de Crisopas. (CIBE 19-016) (6\$207); Mexico, Sinaloa, IMPA Campo Experimental. 29-V-2019. M. L. Ramírez-Ahuja y Enrique Garza. 24.572779-107.454445. Zea mays. Directa de huevos de Crisopas (CIBE 19-017) (2o); Mexico, Sinaloa, Carretera Campo Experimental Impa, El dorado. 29-V-2019. M. L. Ramírez-Ahuja y Enrique Garza. 24.367777-107.370003. Zea mays. Directa de huevos de Crisopas (CIBE 19-018) (4욱); Mexico, Sinaloa, Ingenio El Dorado. 29-V-2019. M. L. Ramírez-Ahuja y Enrique Garza. 24.342501-107.368332. Zea mays. Directa de huevos de Crisopas (CIBE 19-019) (3207); Mexico, Sinaloa, Bebelamas, 30-V-2019. M. L. Ramírez-Ahuja y Enrique Garza. 24.637222-107.273613. Sorgo forrajero. Directa de huevos de Crisopas (CIBE 19-020) (107); Mexico, Culiacán. 30-V-2019. M. L. Ramírez Ahuja y Enrique Garza. 24.633055-107.276665 


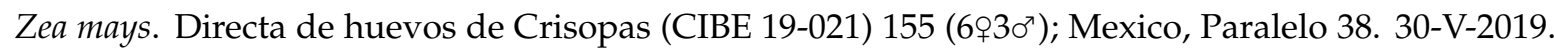
M. L. Ramírez-Ahuja y Enrique Garza. 24.599167-107.481941. Sorgo para grano. Directa de huevos de Crisopas (CIBE 19-022) (2o). Primary molecular vouchers Mexico, Sinaloa, Culiacancito, 28-VIII-2018, Enrique Garza y ML Ramírez-Ahuja, FSCA 00091168 (19)-FSCA 00091169 (10).

\subsubsection{Telenomus tridentatus Johnson and Bin 1982}

Comments: Telenomus tridentatus (Figure 3D) is very similar to Te. lobatus and can be recognized by the male genitalia (Figure 3C): Each digitus with 3 massive, curved teeth; lamina volsellaris in the form of a pair of strongly melanized, apically diverging rods or struts; aedeagal lobe narrow and elongated. The host egg viewed externally appears yellow when parasitized (Figure 3A), and after the emergence of Te. tridentatus it becomes orange (Figure 3B).
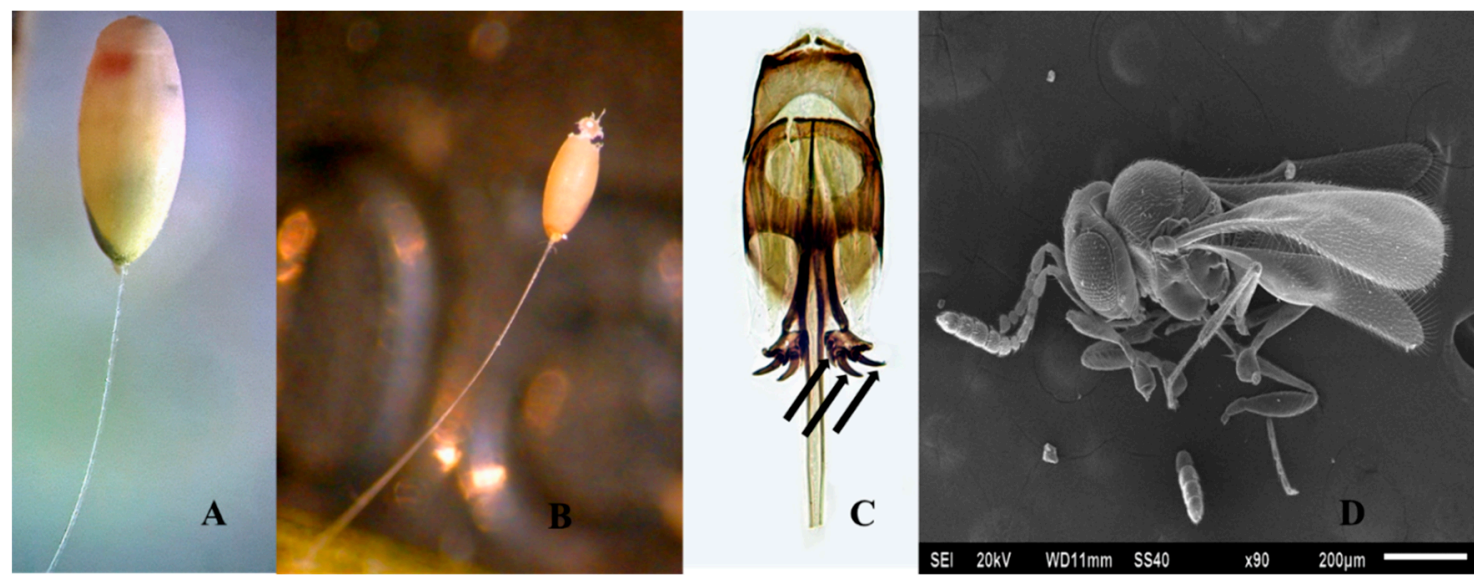

Figure 3. (A) Egg parasitized by Te. tridentatus, (B) Chorion of Chrysopidae abandoned by Te. tridentatus, (C) Male genitalia, medial tooth very close to aedeagal lobe and not clearly visible, (D) Female Te. tridentatus.

Material examined: Mexico, Sinaloa, Guasave. 01, 02-VI-2018, 06-VI-2018, 10, 18, 20-VI-2018, 20, 25-VI-2018. Enrique Garza González (71 specimens); Mexico, Sinaloa, Tabalá (Bebelamas) $3.5 \mathrm{Km}$ Sur de Tabalá. 23-VIII-2018. Enrique Garza González y María de Lourdes Ramírez Ahuja. 24.411330 107.092851. Sorgo forrajero. Directa de huevos de Chrysopidae (CIBE 18-022) (1920`); Mexico, Sinaloa, Culiacancito. 25-V-2019. Enrique Garza. 248480 12-10754137. Zea mays. Directa de huevos de Crisopas (CIBE 19-014) (34웍); Mexico, Sinaloa, Ingenio El Dorado. 27-V-2019. M. L. Ramírez-Ahuja y Enrique Garza. 24.301390-107.377502. Zea mays. Directa de huevos de Crisopas (CIBE 19-173015) (55 $\left.\sigma^{7}\right)$; Mexico, Culiacancito. 27-V-2019. M. L. Ramírez-Ahuja y Enrique Garza. 24.342222-107.368057. Zea mays. Directa de huevos de Crisopas (CIBE 19-016) (5307); Mexico, Sinaloa, IMPA Campo Experimental. 29-V-2019. M. L. Ramírez-Ahuja y Enrique Garza. 24.572779-107.454445. Zea mays. Directa de huevos de Crisopas (CIBE 19-017) (56o ); Mexico, Sinaloa, Carretera Campo Experimental Impa, El dorado. 29-V-2019. M. L. Ramírez-Ahuja y Enrique Garza. 24.367777-107.370003. Zea mays. Directa de huevos de Crisopas (CIBE 19-018) (197ㄲ); Mexico, Sinaloa, Ingenio El Dorado. 29-V-2019. M. L. Ramírez-Ahuja y Enrique Garza. 24.342501-107.368332. Zea mays. Directa de huevos de Crisopas (CIBE 19-019) (29); Mexico, Sinaloa, Bebelamas, 30-V-2019. M. L. Ramírez- Ahuja y Enrique Garza. 24.637222-107.273613. Sorgo forrajero. Directa de huevos de Crisopas (CIBE 19-020) (1910 ); Mexico, Culiacán. 30-V-2019. M. L. Ramírez-Ahuja y Enrique Garza. 24.633055-107.276665. Zea mays. Directa de huevos de Crisopas (CIBE 19-021) (131307); Mexico, Sinaloa, Paralelo 38. 30-V-2019. M. L. Ramírez-Ahuja y Enrique Garza. 24.599167-107.481941. Sorgo para grano. Directa de huevos de Crisopas (CIBE 19-022) (5욷). Primary molecular vouchers Mexico, Sinaloa, Culiacán, VII-2018, Enrique Garza, FSCA $00091170\left(10^{7}\right)$. 


\subsubsection{Trichogramma atopovirilia Oatman y Platner 1983}

Comments: Genital capsule broad, ratio of the width to length greater than 0.5 ; dorsal plate short and generally triangular with subangular apex; the volsellae becomes abruptly thinner in the apical half and with elongated apical spine ending in a point (Figure 4C) [13]. Host egg viewed externally appears like in (Figure 4A); Trichogramma atopovirilia (female Figure 4D) emerges through the sides of the eggs (Figure 4B) but never through the apex as does Te. lobatus.

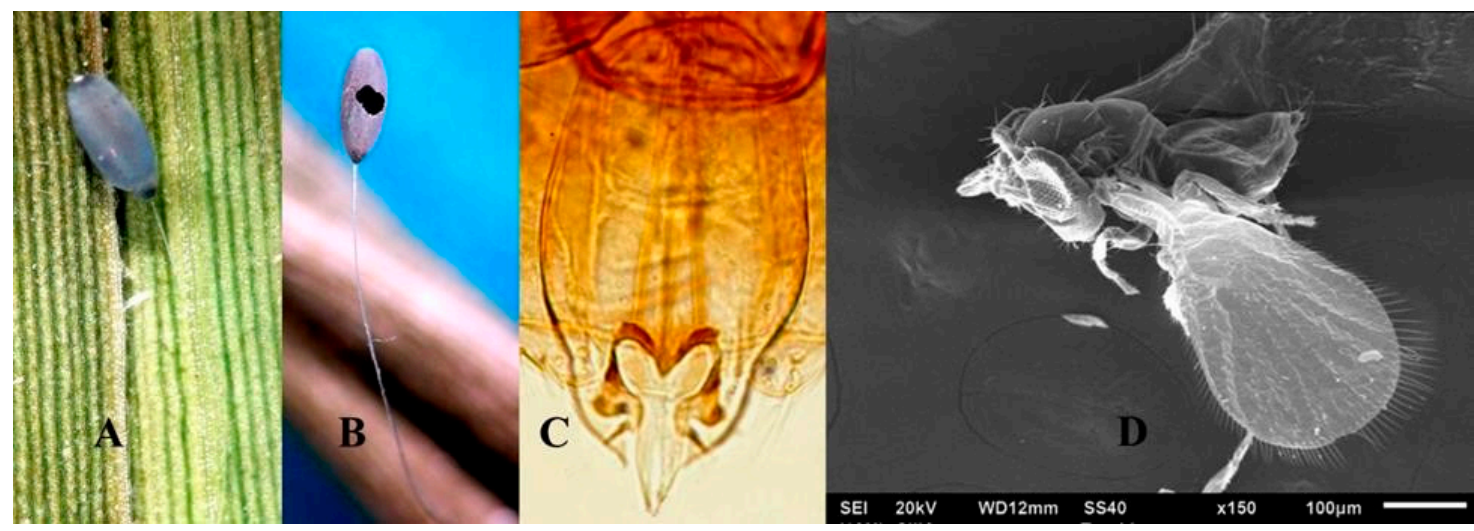

Figure 4. (A) Egg parasitized by Trichogramma atopovirilia, (B) Chorion of chrysopid egg parasitized by Tr. atopovirilia, (C) Male genitalia (photo by Fabián García), (D) Female of Tr. atopovirilia.

Material examined: Mexico, Sinaloa, Guasave. Enrique Garza. 01,10, 18, 20, 25-VI-2018. Enrique Garza González (32 especimens); Mexico, Carretera Culiacán-El Dorado. 25-VIII-2018. Enrique Garza González y M. L. Ramírez Ahuja. 24.505119-107.439178. Sorgo forrajero. En huevos de Chrysopidae (CIBE 18-023) (6 specimens); Mexico, Culiacancito. 25-V-2019. Enrique Garza. $24848012-10754137$. Zea mays. Directa de huevos de Crisopas. (CIBE 19-014) (53ㅜㄱ); Mexico, Sinaloa, Ingenio El Dorado. 27-V-2019. M. L. Ramírez-Ahuja y Enrique Garza. 24.301390-107.377502. Zea mays. Directa de huevos de Crisopas (CIBE 19-015) (54ㅇㄱ); Mexico, Carretera Campo Experimental Impa, El dorado. 29-V-2019. M. L. Ramírez-Ahuja y Enrique Garza. 24.367777-107.370003 Zea mays. Directa de huevos de Crisopas. (CIBE 19-018) (124ㅇㄱ); Mexico, Sinaloa, Ingenio El Dorado. 29-V-2019. M. L. RamírezAhuja y Enrique Garza. 24.342501-107.368332. Zea mays. Directa de huevos de Crisopas. (CIBE 19-019) (19); Mexico, Culiacán. 30-V-2019. M. L. Ramírez-Ahuja y Enrique Garza. 24.633055-107.276665. Zea mays. Directa de huevos de Crisopas (CIBE 19-021) (5107); Mexico, Sinaloa, Paralelo 38. 30-V-2019. M. L. Ramírez-Ahuja y Enrique Garza. 24.599167-107.481941. Sorgo para grano. Directa de huevos de Crisopas (CIBE 19-022) (3원).

\subsubsection{Diversity of Chrysopidae}

During our field collections, we found four species of Chrysoperla: Ch. comanche, Ch. externa, Ch. carnea, Ch. rufilabris; and one species of Cereaochrysa: Ce. valida.

\section{Discussion}

Here we studied the parasitoids of chrysopid eggs in Sinaloa, Mexico, a region where Ch. carnea has been released as the most important biological control agent of $M$. sacchari. Chrysoperla carnea is massively produced in Mexico, as a nationwide strategy for the control of M. sacchari [20], and egg parasitoids can interfere with this biological control effort. Additionally, in Mexico, 21 laboratories commercially produce Ch. carnea, Ch.rufilabris, and Ch. comanche against different pest species [21], further emphasizing the importance of green lacewings in Mexican biocontrol. Trichogramma species are often endoparasitoids of lepidopteran eggs and are used worldwide in biological control programs. In Mexico Tr. atopovirilia, Tr. exiguum and Tr. pretiosum are commercially produced and massively 
released for the control of Eoreuma loftini and Diatraea spp. (Lepidoptera: Pyralidae) in sugarcane [21]. Before this work Tr. atopovirilia had not been reported as parasitoid of chrysopid eggs. Although its parasitism rate is low (Tables 2 and 3), it must be considered as part of the biological control ecosystem. Telenomus lobatus and Te. tridentatus have been recorded in the United States attacking eggs of Chrysopidae and Lomamyia flavicornis Walker (Neuroptera: Berothidae) [8]. It has been reported that Te. lobatus can parasitize Chrysoperla rufilabris and Ch. carnea [8] with rates as high as 65\% [12], and even higher rates have been observed [11]. In this work we did not determine the chrysopid eggs parasitized by Te. lobatus to the level of species. However, it should be noted that Ch. rufilabris and Ch. carnea were found in the places that we sampled in Sinaloa. It was not possible to determined that the highest percentage of parasitism was 35.57\% in Guasave during 2018. In that year we collected eggs parasitized by Telenomus spp. and Tr. atopovirilia, but no M. chrysopae were collected. The coloration of eggs parasitized by Te. lobatus and Tr. atopovirilia are very similar when they are parasitized, but they can be distinguished by the emergence hole of the adult wasp. In Te. lobatus the hole is always at the apex of the egg whereas Tr. atopovirilia can exit from any side of the egg but not the apex. Telenomus lobatus and Te. tridentatus can be distinguished by male genitalia and egg color during development and after adult emergence. It was observed that Telenomus species prefer to oviposit in newly laid eggs, similar to what Ruberson [12] reported. Based on our observations, in areas in which Te. lobatus and Te. tridentatus occur, augmentative releases of Chrysoperla carnea should be conducted with mature chrysopid eggs to avoid parasitism. According to the results obtained in this study, parasitoid activity on populations of Chrysopidae must be considered in biological control and integrated pest management (IPM) programs because of the effect on predator efficacy. There is a need for more research on these parasitoids to know exactly which species of Chrysopidae are parasitized. There are now methods by which one can sequence residual DNA of both host and parasitoid from the empty egg. The methods described in Gariepy et al. [22] were recently used by Lomeli-Flores et al. [23] to define species-level trophic interactions. Future studies may employ this method to match DNA from the host egg with the adults and determine them at the species level.

\section{Conclusions}

This study showed that M. chrysopae, Te. lobatus, Te. tridentatus, and Tr. atopovirilia are parasitoids of Chrysopidae eggs in Culiacan, Mexico. This finding has important implications for the development of biological control and IPM programs using Chrysopidae against different pest species.

Author Contributions: Conceptualization, M.d.L.R.-A., E.G.-G., and I.P.R.-S.; methodology, M.d.L.R.-A., E.G.-G., E.J.T., M.A.G.-G., and P.Z.-R.; software, E.J.T., and P.Z.-R.; validation, M.d.L.R.-A., E.G.-G., E.J.T., and I.P.R.-S.; formal analysis, E.G.-G.; investigation, M.d.L.R.-A., E.G.-G., and E.J.T.; resources, E.G.-G., I.P.R.-S., E.J.T., M.A.R.-P., and P.Z.-R.; data curation, M.d.L.R.-A., E.G.-G., and E.J.T.; writing—original draft preparation, M.d.L.R.-A., E.G.-G., and I.P.R.-S.; writing-review and editing, E.J.T., M.A.R.-P., E.R.-T.; visualization, M.d.L.R.-A., E.J.T.; supervision, I.P.R.-S.; funding acquisition, E.G.-G., and I.P.R.-S. All authors have read and agreed to the published version of the manuscript.

Funding: This research received no external funding.

Acknowledgments: M.d.L.R.-A. is grateful to the Consejo Nacional de Ciencia y Tecnología (CONACYT, Mexico) for the scholarship granted for her Doctorate studies and to Ing. Eduardo Torres Sánchez and Unidad de Reproducción de Insectos Benéficos de Sinaloa for provide Sitotroga cerealella eggs. Matthew Moore, Cheryl Roberts and Lynn Combee (FDCAS-DPI) for their assistance with generating CO1 barcodes. This work was partially funded by Agrobionsa, Agrobiológicos del Noroeste. Elijah Talamas was supported by the Florida Department of Agriculture and Consumer Services, Division of Plant Industry.

Conflicts of Interest: The authors declare no conflict of interest. 


\section{References}

1. Cortez-Mondaca, E.; López-Arroyo, J.I.; Rodríguez-Ruíz, L.; Partida-Valenzuela, M.P.; Pérez-Márquez, J. Chrysopidae species associated with Diaphorina citri Kuwayama in citrus and predation capacity of Sinaloa, México. Rev. Mex. Cienc. Agric. 2016, 7, 363-374.

2. Cortez-Mondaca, E.; Orduño-Cota, F.J.; López-Buitimea, M. Species of Chrysopidae Associated with Whiteflies in Soybean in Northern Sinaloa, Mexico. Southwest. Entomol. 2008, 33, 153-155. [CrossRef]

3. Cortez-Mondaca, E.; Orduño-Cota, F.J.; Edgardo, C.M. Estrategias para un Manejo Integrado de Escama Parlatoria del Mango, en el Norte de Sinaloa; Campo Experimental Valle de El Fuerte del INIFAP: Sinaloa, México, 2008; p. 36.

4. Maya, V.; Castillo, Y.H. Manejo Integrado del Pulgón Amarillo del Sorgo. In Boletín Electrónico 1; INIFAP, CIR-Noreste; Campo experimental Río Bravo: Tamaulipas, Mexico, 2015.

5. Cortez-Mondaca, E.; López-Buitimea, M.; López-Arroyo, J.I.; Orduño-Cota, F.J.; Herrera-Rodríguez, G. Chysopidae Species Associated with the Sugarcane Aphid in Northern Sinaloa, Mexico. Southwest. Entomol. 2016, 41, 541-545. [CrossRef]

6. Noyes, J.S. Universal Chalcidoidea Database. World Wide Web Electronic Publication. Available online: http://www.nhm.ac.uk/chalcidoids (accessed on 6 September 2019).

7. Myartseva, S.N.; Shuvakhina, E.Y. Species of the genus Ooencyrtus Ashmead (Hymenoptera, Encyrtidae), lacewing egg parasites (Neuroptera, Chrysopidae) in North and South America. Entomol. Obozr. 2004, 83, 248-254.

8. Johnson, N.F.; Bin, F. Species of Telenomus (Hym., Scelionidae), parasitoids of stalked eggs of Neuroptera (Chrysopidae \& Berothidae). Redia 1982, 65, 189-206.

9. Loiácono, M.S.; Lanati, S.J.; Neila, C. Una especie nueva del género Telenomus (Hymenoptera: Scelionidae) parasitoide de posturas de Chrysopidae (Neuroptera) en Mendoza, Argentina. Rev. Soc. Entomol. Argent. 2006, 65, 23-26.

10. Yashiro, N.; Hirose, Y.; Honda, J.Y.; Takeuchi, Y.; Yashiro, T. A new species of Trichogramma (Hymenoptera: Trichogrammatidae) parasitic on eggs of the alderfly Sialis melania (Neuroptera: Sialidae) from Japan, with comments on its phylogeny and male wing polymorphism. Entomol. Sci. 2012, 15, 189-196. [CrossRef]

11. Ruberson, J.R.; Tauber, C.A.; Tauber, M.J. Development and survival of Telenomus lobatus, a parasitoid of chrysopid eggs: Effect of host Species. Entomol. Exp. Appl. 1989, 51, 101-106. [CrossRef]

12. Ruberson, J.R.; Tauber, C.A.; Tauber, M.J. Developmental Effects of Host and Temperature on Telenomus spp. (Hymenoptera: Scelionidae) Parasitizing Chrysopid Eggs. Biol. Control 1995, 5, 245-250. [CrossRef]

13. Pinto, J.D. Systematics of the North American species of Trichogramma Westwood (Hymenoptera: Trichogrammatidae). Mem. Entomol. Soc. Wash. 1998, 22, 1-287.

14. Polaszek, A.; Kimani, S.W. Telenomus species (Hymenoptera: Scelionidae) attacking eggs of pyralid pest (Lepidoptera) in Africa: A rewiev and guide to identification. Bull. Entomol. Res. 1990, 80, 57-71. [CrossRef]

15. Tauber, C.A. Systematics of North American chrysopid larvae: Chrysopa carnea group (Neuroptera). Can. Entomol. 1974, 106, 1133-1153. [CrossRef]

16. Brooks, S.J. A taxonomic review of the common green lacewing genus Chrysoperla (Neuroptera: Chrysopidae). Bull. Br. Mus. Nat. Hist. Entomol. 1994, 63, 137-210.

17. Tauber, C.A.; De León, T.; Penny, N.D.; Tauber, M.J. The genus Ceraeochrysa (Neuroptera: Chrysopidae) of America north of Mexico: Larvae, adults, and comparative biology. Ann. Entomol. Soc. Am. 2000, 93, 1195-1221. [CrossRef]

18. Giantsis, I.A.; Chaskopoulou, A.; Bon, M.C. Mild-Vectolysis: A nondestructive DNA extraction method for vouchering sand flies and mosquitoes. J. Med. Entomol. 2016, 53, 692-695. [CrossRef]

19. Folmer, O.; Black, M.; Hoeh, W.; Lutz, R.; Vrijenhoek, R. DNA primers for amplification of mitocondrial cytochrome c oxidase subunit I from diverse metazoan invertebrates. Mol. Mar. Biol. Biotechnol. 1994, 3, 294-299. [PubMed]

20. SENASICA, Servicio Nacional de Sanidad, Inocuidad y Calidad Agroalimentaria. Insectos Benéficos Contra Pulgón Amarillo. Available online: https://www.gob.mx/senasica/articulos/insectos-beneficos-contrapulgon-amarillo (accessed on 6 September 2019). 
21. Arredondo-Bernal, H.C. Directorio de Laboratorios Reproductores y Comercializadores de Agentes de Control Biológico en México; Servicio Nacional de Sanidad, Inocuidad y Calidad Agroalimentaria Dirección General de Sanidad Vegetal: Ciudad de Mexico, Mexico, 2019; p. 25.

22. Gariepy, T.D.; Bruin, A.; Konopka, J.; Scott-Dupree, C.; Fraser, H.; Bon, M.C.; Talamas, E. A modified DNA barcode approach to define trophic interactions between native and exotic pentatomids and their parasitoids. Mol. Ecol. 2019, 28, 456-470. [CrossRef]

23. Lomeli-Flores, J.R.; Rodríguez-Rodríguez, S.E.; Rodríguez-Levya, E.; González-Hernández, H.; Gariepy, T.D.; Talamas, E.J. Field studies and molecular forensics identify a new association: Idris elba Talamas, sp. nov. parasitizes the eggs of Bagrada hilaris (Burmeister). J. Hymenopt. Res. 2019, 73, 125. [CrossRef]

Publisher's Note: MDPI stays neutral with regard to jurisdictional claims in published maps and institutional affiliations.

(C) 2020 by the authors. Licensee MDPI, Basel, Switzerland. This article is an open access article distributed under the terms and conditions of the Creative Commons Attribution (CC BY) license (http://creativecommons.org/licenses/by/4.0/). 